\title{
Diurnal variations of reactive chlorine and nitrogen oxides observed by MIPAS-B inside the January 2010 Arctic vortex
}

\author{
G. Wetzel ${ }^{1}$, H. Oelhaf ${ }^{1}$, O. Kirner ${ }^{2}$, F. Friedl-Vallon ${ }^{1}$, R. Ruhnke ${ }^{1}$, A. Ebersoldt ${ }^{3}$, A. Kleinert ${ }^{1}$, G. Maucher ${ }^{1}$, \\ H. Nordmeyer ${ }^{1}$, and J. Orphal ${ }^{1}$ \\ ${ }^{1}$ Karlsruhe Institute of Technology, Institute for Meteorology and Climate Research, Karlsruhe, Germany \\ ${ }^{2}$ Karlsruhe Institute of Technology, Steinbuch Centre for Computing, Karlsruhe, Germany \\ ${ }^{3}$ Karlsruhe Institute of Technology, Institute for Data Processing and Electronics, Karlsruhe, Germany
}

Correspondence to: G. Wetzel (gerald.wetzel@kit.edu)

Received: 11 November 2011 - Published in Atmos. Chem. Phys. Discuss.: 13 February 2012

Revised: 20 June 2012 - Accepted: 3 July 2012 - Published: 25 July 2012

\begin{abstract}
The winter 2009/2010 was characterized by a strong Arctic vortex with extremely cold mid-winter temperatures in the lower stratosphere associated with an intense activation of reactive chlorine compounds $\left(\mathrm{ClO}_{\mathrm{x}}\right)$ from reservoir species. Stratospheric limb emission spectra were recorded during a flight of the balloon version of the Michelson Interferometer for Passive Atmospheric Sounding (MIPAS-B) from Kiruna (Sweden) on 24 January 2010 inside the Arctic vortex. Several fast limb sequences of spectra (in time steps of about $10 \mathrm{~min}$ ) were measured from nighttime photochemical equilibrium to local noon allowing the retrieval of chlorine- and nitrogen-containing species which change rapidly their concentration around the terminator between night and day. Mixing ratios of species like $\mathrm{ClO}, \mathrm{NO}_{2}$, and $\mathrm{N}_{2} \mathrm{O}_{5}$ show significant changes around sunrise, which are temporally delayed due to polar stratospheric clouds reducing the direct radiative flux from the sun. $\mathrm{ClO}$ variations were derived for the first time from MIPAS-B spectra. Daytime $\mathrm{ClO}$ values of up to $1.6 \mathrm{ppbv}$ are visible in a broad chlorine activated layer below $26 \mathrm{~km}$ correlated with low values (below $0.1 \mathrm{ppbv}$ ) of the chlorine reservoir species $\mathrm{ClONO}_{2}$. Observations are compared and discussed with calculations performed with the 3-dimensional Chemistry Climate Model EMAC (ECHAM5/MESSy Atmospheric Chemistry). Mixing ratios of the species $\mathrm{ClO}, \mathrm{NO}_{2}$, and $\mathrm{N}_{2} \mathrm{O}_{5}$ are well reproduced by the model during night and noon. However, the onset of $\mathrm{ClO}$ production and $\mathrm{NO}_{2}$ loss around the terminator in the model is not consistent with the measurements. The MIPAS-B observations along with Tropospheric UltravioletVisible (TUV) radiation model calculations suggest that po-
\end{abstract}

lar stratospheric clouds lead to a delayed start followed by a faster increase of the photodissoziation of $\mathrm{ClOOCl}$ and $\mathrm{NO}_{2}$ near the morning terminator since stratospheric clouds alter the direct and the diffuse flux of solar radiation. These effects are not considered in the EMAC model simulations which assume a cloudless atmosphere.

\section{Introduction}

Chemically active chlorine species $\left(\mathrm{ClO}_{\mathrm{x}}=\mathrm{Cl}+\mathrm{ClO}+2\right.$ $\mathrm{ClOOCl}$ ), which are part of total inorganic chlorine $\mathrm{Cl}_{\mathrm{y}}$, play a dominant role in the catalytic destruction of stratospheric ozone at the end of the polar winter season when cold temperatures and polar stratospheric clouds (PSC) have previously enabled chlorine compounds (mainly $\mathrm{Cl}_{2}$ ) to be produced from its reservoir species $\left(\mathrm{ClONO}_{2}, \mathrm{HCl}\right.$, and $\left.\mathrm{HOCl}\right)$ via heterogeneous chemical reactions (Solomon et al. 1986). In the sunlit atmosphere, these compounds are photolyzed to yield $\mathrm{Cl}$ atoms and subsequently chlorine monoxide $(\mathrm{ClO})$. When high (daytime) $\mathrm{ClO}$ concentrations $(\geq 0.5 \mathrm{ppbv})$ are present in the lower stratosphere the $\mathrm{ClO}-\mathrm{ClO}$ dimer cycle governs (besides the $\mathrm{ClO}-\mathrm{BrO}$ cycle) the destruction of polar ozone (see, e.g., Molina et al. 1987; Brasseur and Solomon, 2005):

$$
\begin{aligned}
& \mathrm{ClO}+\mathrm{ClO}+\mathrm{M} \rightleftarrows \mathrm{ClOOCl}+\mathrm{M} \\
& \mathrm{ClOOCl}+h v \rightarrow \mathrm{Cl}+\mathrm{ClOO} \\
& \mathrm{ClOO}+\mathrm{M} \rightarrow \mathrm{Cl}+\mathrm{O}_{2}+\mathrm{M}
\end{aligned}
$$


$\mathrm{Cl}+\mathrm{O}_{3} \rightarrow \mathrm{ClO}+\mathrm{O}_{2}$

Taking into account Reaction (R4) twice in this scheme, the complete catalytic cycle leads to a net reduction of ozone by $2 \mathrm{O}_{3}+h v \rightarrow 3 \mathrm{O}_{2}$. The diurnal variation of the concentration of $\mathrm{ClO}$ and its dimer is controlled by this reaction scheme. During night, high $\mathrm{ClOOCl}$ amounts of about $1 \mathrm{ppbv}$ were observed in activated Arctic vortex air in situ (Stimpfle et al., 2004) and by remote sensing with the balloon-borne Michelson Interferometer for Passive Atmospheric sounding (MIPAS-B; Wetzel et al., 2010). During day, volume mixing ratios (VMR) below 0.5 ppbv have been measured inside the vortex by in-situ instruments in the lower stratosphere (Stimpfle et al., 2004, von Hobe et al., 2007). In contrast, high Arctic $\mathrm{ClO}$ daytime mixing ratios around 2 ppbv were inferred from satellite observations of the Microwave Limb Sounder (MLS; Santee et al., 2003, 2008) and MIPAS on ENVISAT (Glatthor et al., 2004) during time periods of chlorine activation. During nighttime, mixing ratios usually are not higher than 0.5 ppbv (Glatthor et al., 2004). By the end of polar winter, increasing illumination enhances the production of $\mathrm{NO}_{2}$ (mainly by $\mathrm{HNO}_{3}$ photolysis and its reaction with $\mathrm{OH}$ ) such that the competing reaction:

$\mathrm{ClO}+\mathrm{NO}_{2}+\mathrm{M} \rightarrow \mathrm{ClONO}_{2}+\mathrm{M}$

transfers active chlorine back into the important reservoir species $\mathrm{ClONO}_{2}$ (see, e.g., Müller et al., 1994; Douglass et al., 1995). Hence, by the end of Arctic winter, high values of more than 2 ppbv $\mathrm{ClONO}_{2}$ have been measured (see, e.g., Oelhaf et al., 1994; Dufour et al., 2006; Höpfner et al., 2007; Wetzel et al., 2010).

In the absence of sunlight in the deep polar winter, $\mathrm{NO}_{\mathrm{x}}$ $\left(\mathrm{NO}+\mathrm{NO}_{2}+\mathrm{NO}_{3}\right)$ is converted to the longer-lived reservoir species $\mathrm{HNO}_{3}, \mathrm{~N}_{2} \mathrm{O}_{5}$, and $\mathrm{ClONO}_{2}$ in the gas phase. $\mathrm{ClONO}_{2}$ and $\mathrm{N}_{2} \mathrm{O}_{5}$ are further converted to $\mathrm{HNO}_{3}$ via heterogeneous reactions on particles of PSC. These reactions activate chlorine and lead to a $\mathrm{HNO}_{3}$ condensation on PSC particles which may sediment when they are large enough (Fahey, et al., 2001). This redistribution leads to an irreversible removal of $\mathrm{HNO}_{3}$ at higher altitudes (denitrification) together with an excess of $\mathrm{HNO}_{3}$ due to evaporation at lower altitudes (renitrification). Intense denitrification events can thus delay $\mathrm{ClONO}_{2}$ recovery via Reaction (R5) leading to an enhanced ozone destruction (see, e.g. Waibel et al., 1999).

The species $\mathrm{NO}_{2}$ in general regulates the global ozone budget via reactions with radicals to form reservoir species like $\mathrm{ClONO}_{2}, \mathrm{HNO}_{3}, \mathrm{~N}_{2} \mathrm{O}_{5}, \mathrm{HO}_{2} \mathrm{NO}_{2}$, and $\mathrm{BrONO}_{2}$ which temporarily remove these radicals from ozone destroying reactions. $\mathrm{NO}_{2}$ is in photochemical equilibrium with NO. At sunset, $\mathrm{NO}$ is converted to $\mathrm{NO}_{2}$ mainly via the reaction with ozone (see, e.g., Brasseur and Solomon, 2005):

$\mathrm{NO}+\mathrm{O}_{3} \rightarrow \mathrm{NO}_{2}+\mathrm{O}_{2}$

followed by reactions producing $\mathrm{N}_{2} \mathrm{O}_{5}$ :

$\mathrm{NO}_{2}+\mathrm{O}_{3} \rightarrow \mathrm{NO}_{3}+\mathrm{O}_{2}$
$\mathrm{NO}_{2}+\mathrm{NO}_{3}+\mathrm{M} \rightleftarrows \mathrm{N}_{2} \mathrm{O}_{5}+\mathrm{M}$

After sunrise, $\mathrm{N}_{2} \mathrm{O}_{5}$ is photolyzed back into $\mathrm{NO}_{2}$ and $\mathrm{NO}_{3}$ :

$\mathrm{N}_{2} \mathrm{O}_{5}+h v \rightarrow \mathrm{NO}_{2}+\mathrm{NO}_{3}$

$\mathrm{NO}_{3}+h v \rightarrow \mathrm{NO}_{2}+\mathrm{O}\left({ }^{3} \mathrm{P}\right)$

It can also be destroyed by thermal decomposition via the reverse of Reaction (R8). During day, $\mathrm{NO}_{2}$ reacts rapidly to reform NO either by reaction with atomic oxygen (upper stratosphere) or photolysis:

$\mathrm{NO}_{2}+\mathrm{O}\left({ }^{3} \mathrm{P}\right) \rightarrow \mathrm{NO}+\mathrm{O}_{2}$

$\mathrm{NO}_{2}+h v \rightarrow \mathrm{NO}+\mathrm{O}\left({ }^{3} \mathrm{P}\right)$

Stratospheric $\mathrm{NO}_{2}$ and $\mathrm{N}_{2} \mathrm{O}_{5}$ measurements have been carried out since many years. The first simultaneous MIPASB $\mathrm{NO}_{2}$ and $\mathrm{N}_{2} \mathrm{O}_{5}$ measurement took place in February 1995 (Wetzel et al., 1997). Spatio-temporal variations of $\mathrm{NO}_{2}, \mathrm{~N}_{2} \mathrm{O}_{5}$, and other nitrogen-containing constituents were detected in the late winter Arctic vortex in March 2003 (Wiegele et al., 2009). Satellite observations of MIPAS on ENVISAT and the Atmospheric Chemistry Experiment Fourier Transform Spectrometer (ACE-FTS) have shown the large variability of these species depending on diurnal illumination (see, e.g., Mengistu Tsidu et al., 2005; Funke et al., 2005; Wetzel et al., 2007; Kerzenmacher et al., 2008; Wolff et al., 2008). In this paper we focus on Arctic stratospheric mixing ratios of chlorine and nitrogen species which change quickly their concentration around the terminator between night and day. Retrieved trace gas profiles were deduced from limb emission spectra recorded around sunrise during a MIPAS-B flight from Kiruna (Sweden) on 24 January 2010 inside the activated polar vortex. These data are compared to the 3-dimensional Chemistry Climate Model (CCM) EMAC (ECHAM5/MESSy Atmospheric Chemistry model).

\section{MIPAS-B observations and meteorological situation}

The balloon-borne limb-emission sounder MIPAS-B is a cryogenic Fourier Transform spectrometer which covers the mid-infrared spectral range from about 4 to $14 \mu \mathrm{m}$. MIPASB spectra are characterized by their high spectral resolution (about $0.07 \mathrm{~cm}^{-1}$ after apodization) which allows the separation of individual spectral lines from continuum-like emissions in combination with a high radiometric accuracy with a $1-\sigma$ gain error of typically $1 \%$. Typical values of the noise equivalent spectral radiance (NESR) are within $1 \times 10^{-9}$ and $7 \times 10^{-9} \mathrm{~W}\left(\mathrm{~cm}^{-2} \mathrm{srcm}^{-1}\right)$ for a single calibrated spectrum. Averaging over $n(n \leq 20)$ spectra per single elevation scan reduces the spectral noise by a factor of $1 / \sqrt{n}$. The instrument is distinguished by a high performance and flexibility of the pointing system with an after-all knowledge of the tangent altitude of better than $50 \mathrm{~m}$ at the 1- $\sigma$ confidence limit. 
A comprehensive overview and description of the instrument together with processing of recorded interferograms to calibrated spectra including phase correction, Fast Fourier Transformation to the spectral domain, and two-point calibration of the spectra from arbitrary to radiance units is given by Friedl-Vallon et al. (2004) and references therein. This paper further includes instrument characterization in terms of the instrumental line shape, field of view, NESR, line of sight of the instrument, detector nonlinearity and the error budget of the calibrated spectra.

The Arctic winter 2009/2010 started comparatively warm until the first half of December. However, from midDecember until end of January, temperatures in the lower stratosphere were unusually cold and fell below the frost point $T_{\text {ice }}$ on a synoptic scale (Pitts et al., 2011). By the end of January, a major stratospheric warming initiated by a planetary wave with wave number one developed which displaced the cold pool of air away from the centre of the vortex and marked the beginning of a gradual break-up of the vortex due to increasing baroclinity. However, temperatures at $30 \mathrm{hPa}(\sim 23 \mathrm{~km})$ remained below the climatological mean until the end of January (Pitts et al., 2011). Even though the final warming of the vortex took place already in mid-February, the January 2010 winter was one of the coldest in the lower stratosphere during the last decades. The MIPAS-B flight took place on 24 January 2010 over northern Scandinavia inside the Arctic vortex at the beginning of this major warming. This phase of the vortex was dominated by liquid supercooled ternary solution (STS) PSC (Pitts et al., 2011). After the balloon was successfully launched from Esrange near Kiruna (Sweden) it reached its float level at about $34 \mathrm{~km}$. All recorded limb sequences are depicted in Fig. 1. From nighttime photochemical equilibrium until local noon, several fast sequences of spectra were measured in time steps of about $10 \mathrm{~min}$ to allow the retrieval of photochemically active species which change quickly their concentration around the terminator between night and day (Seq. 05a-Seq. 09b; 06:16 UTC-10:20 UTC). For this purpose the line of sight of the instrument was aligned perpendicular to the azimuth direction of the sun to allow for a symmetric illumination of the sounded air mass before and beyond the tangent point. The variation of the solar zenith angle (SZA) during the observations is shown in Fig. 2. Local noon occurs at 09:57 UTC. All sequences exhibit some continuum-like emissions due to the occurrence of PSC in the spectra at altitudes below $25 \mathrm{~km}$ in line with low colour ratios of three different spectral regions as defined by Spang et al. (2004) and Höpfner et al. (2006). From these colour ratios, PSC seem to consist mainly of STS or small NAT (nitric acid trihydrate) particles with radii less than $3 \mu \mathrm{m}$ or a mixture of both. PSC observations carried out on the same day by the Esrange lidar also exhibit mixed and STS particles between 17 and $25 \mathrm{~km}$ (Khosrawi et al., 2011). 20 scans with different elevation angles from $34 \mathrm{~km}$ down to $13 \mathrm{~km}$ have been analyzed per sequence.

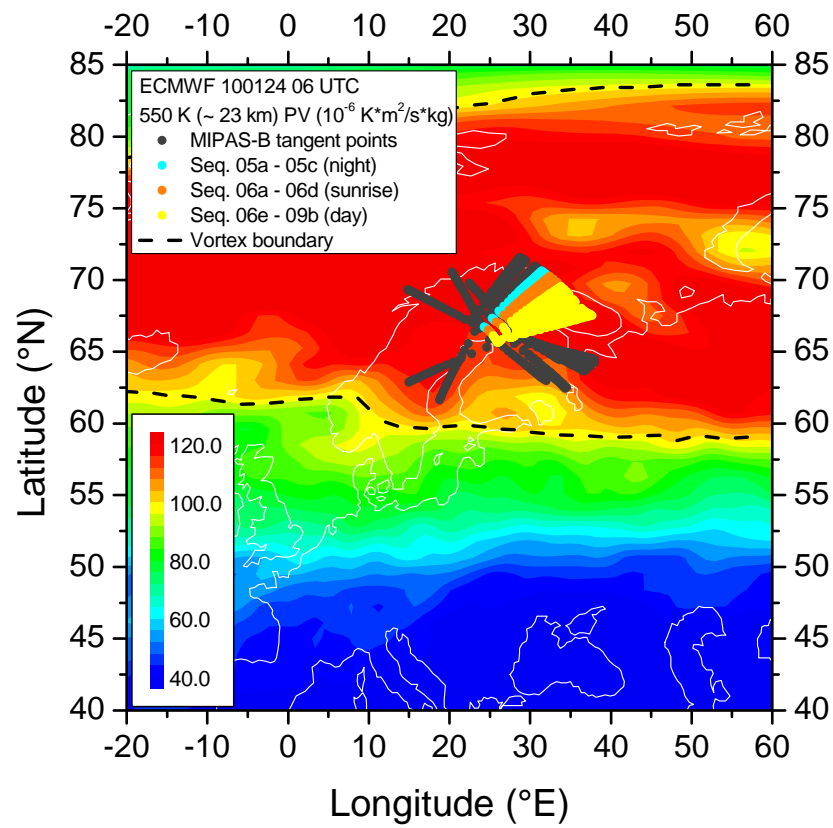

Fig. 1. Potential vorticity (PV) field from European Centre for Medium-Range Weather Forecasts (ECMWF) analysis on 24 January 2010, 06:00 UTC. MIPAS-B tangent points are plotted as solid circles. Sequences observed during night, close to sunrise, and during day are marked with different colours. The vortex boundary which represents the strongest PV gradient (Nash et al., 1996) is shown as dashed line.

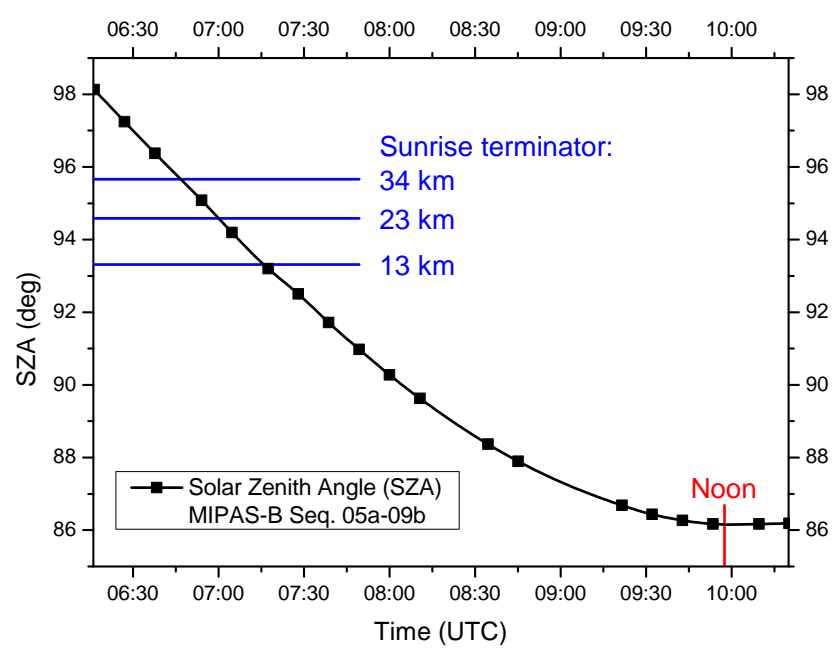

Fig. 2. Variation of the solar zenith angle (SZA) for MIPAS-B measured limb sequences 05a-09b (24 January 2010). Each black square denotes one recorded limb sequence. Altitude dependent local sunrise is given by the intersection of the black SZA line with the corresponding blue horizontal lines. Local noon is marked by a red line. 


\section{Data analysis and model calculations}

Radiance calculations were performed with the Karlsruhe Optimized and Precise Radiative transfer Algorithm (KOPRA; Stiller et al., 2002) which is a line-by-line and layer-by-layer model to simulate the infra-red radiative transfer through the atmosphere. Molecular spectroscopic parameters for the calculation of limb emission spectra were taken from the HITRAN database (Rothman et al., 2005). KOPRA also calculates derivatives of the radiance spectrum with respect to atmospheric state and instrument parameters and thus provides the Jacobians for the retrieval procedure KOPRAFIT (Höpfner et al., 2002). While the vertical distance of observed tangent altitudes ranges between 0.8 and $1.5 \mathrm{~km}$, the retrieval grid was set to $1 \mathrm{~km}$ up to the balloon float altitude. Above, the vertical spacing increases to $10 \mathrm{~km}$ at the upper altitude at $100 \mathrm{~km}$. Taking into account the instrumental field of view, the retrieval grid is finer than the achievable vertical resolution of the measurement for a large part of the altitude region covered. To avoid retrieval instabilities due to this oversampling of the vertical retrieval grid, a Tikhonov-Phillips regularization approach (Phillips, 1962; Tikhonov, 1963) was applied which was constrained with respect to a height-constant zero a priori profile $\boldsymbol{x}_{\mathrm{a}}$ of the target species:

$\boldsymbol{x}_{i+1}=\boldsymbol{x}_{i}+\left[\mathbf{K}_{i}^{T} \mathbf{S}_{y}^{-1} \mathbf{K}_{i}+\mathbf{R}\right]^{-1}\left[\mathbf{K}_{i}^{T} \mathbf{S}_{y}^{-1}\left(\boldsymbol{y}_{\text {meas }}-\boldsymbol{y}\left(\boldsymbol{x}_{i}\right)\right)-\mathbf{R}\left(\boldsymbol{x}_{i}-\boldsymbol{x}_{\mathrm{a}}\right)\right]$

Where $\boldsymbol{x}_{i+1}$ is the vector of the wanted state parameters $\boldsymbol{x}_{i}$ for iteration $i+1 ; \boldsymbol{y}_{\text {meas }}$ is the measurement vector and $\boldsymbol{y}\left(\boldsymbol{x}_{i}\right)$ the calculation of the radiative transfer model using state parameters of iteration number $i$; $\mathbf{K}$ is the Jacobian matrix containing partial derivatives $\partial \boldsymbol{y}\left(\boldsymbol{x}_{i}\right) / \partial \boldsymbol{x}_{i}$ while $\mathbf{S}_{y}^{-1}$ is the inverse noise measurement covariance matrix and $\mathbf{R}$ a regularization matrix with the first derivative operator.

For the temperature retrieval, a first derivative a priori constraint was used. This state parameter was derived first by using appropriate $\mathrm{CO}_{2}$ lines of two separate bands around $810 \mathrm{~cm}^{-1}$ and $950 \mathrm{~cm}^{-1}$ and a priori pressure-temperature information from ECMWF together with a $\mathrm{CO}_{2}$ VMR profile updated with data from NOAA ESRL GMD (National Oceanic and Atmospheric Administration, Earth System Research Laboratory, Global Monitoring Division; Montzka et al., 1999). The temperature retrieval 1- $\sigma$ accuracy is estimated to be within about $1 \mathrm{~K}$. Then, VMR profiles of the target species are individually retrieved in selected spectral regions (see Table 1). A detailed overview on the analysis of nitrogen- and chlorine-containing molecules is given in Wetzel et al. $(2002,2010)$. The error estimation of the target parameter consists of random and systematic errors which were added quadratically to yield the total error which refers to the $1-\sigma$ confidence limit. Random errors include spectral noise as well as covariance effects of the simultaneously fitted parameters. Systematic errors mainly comprise spectroscopic data inaccuracies (band intensities), uncertainties in the line of sight, and gain calibration errors. The altitude resolution is calculated from the number of degrees of freedom of the retrieval which corresponds to the trace of the averaging kernel matrix. Typical values for the retrieved parameters are given in Table 1.

Measured MIPAS-B data are compared to simulations performed with the Chemistry Climate Model EMAC developed at the Max-Planck-Institute for Chemistry in Mainz (Jöckel et al., 2006). EMAC is a combination of the general circulation model ECHAM5 (Roeckner et al., 2006) and several submodels like the chemistry module MECCA (Sander et al., 2005) and the microphysical submodel PSC (Kirner et al., 2011) combined through the interface Modular Earth Submodel System (MESSy; Jöckel et al., 2005).

Data from a two years simulation until January 2010 with EMAC Version 1.10 were taken for this study. The simulation was carried out with a time step of $10 \mathrm{~min}$ and a T42 $\left(2.8^{\circ} \times 2.8^{\circ}\right)$ horizontal resolution with 90 vertical layers from the surface up to $0.01 \mathrm{hPa}(\sim 80 \mathrm{~km})$. A Newtonian relaxation technique of the prognostic variables temperature, vorticity, divergence and the surface pressure above the boundary layer and below $1 \mathrm{hPa}$ towards ECMWF operational analysis has been applied in order to nudge the model dynamics towards the ECMWF one. Sensitivity studies with different EMAC runs have shown that nudging up to the upper stratosphere is important to reproduce the observed stratospheric temperature distribution which governs the formation of PSC and therefore the amount of active chlorine. The parameterization of NAT is based on the efficient growth and sedimentation of NAT particles as described in Kirner et al. (2011). The NAT formation takes place below the NAT existence temperature ( $\left.T_{\mathrm{NAT}}\right)$ with the assumption of a necessary super cooling of $3 \mathrm{~K}$. The STS formation is based on Carslaw et al. (1995) and takes place through uptake of nitric acid $\left(\mathrm{HNO}_{3}\right)$ by liquid sulphuric acid aerosols. During cooling of STS the fraction of $\mathrm{HNO}_{3}$ increases in the particles. Boundary conditions for greenhouse gases are from the IPCC-A1B scenario (IPCC, 2001) and adapted to observations from the AGAGE database (Prinn et al., 2001). Halogenated hydrocarbons are included according to the WMO$\mathrm{Ab}$ scenario (WMO, 2007). The simulation includes a comprehensive chemistry setup from the troposphere to the lower mesosphere with 98 gas phase species, 178 gas phase reactions, 60 photolysis reactions, and 10 heterogeneous reactions on liquid aerosols, NAT- and ice particles. In comparison between the reactivity of NAT and liquid aerosols, the activation of $\mathrm{ClO}_{\mathrm{x}}$ takes place mainly at liquid aerosols. The calculation of the photolysis rates is based on the fast on-line scheme by Landgraf and Crutzen (1998), which accounts for spherical geometry by employing an air mass factor correction with an extrapolation of the calculated photolysis rates for solar zenith angles between 88 and 94.5 degrees. Rate constants of gas-phase reactions are mainly taken from the compilation of Sander et al. (2003). Absorption cross sections from the same compilation have been chosen for the photolysis rate calculations of $\mathrm{ClOOCl}$. However, a 
Table 1. Set-up for MIPAS-B trace gas retrievals and typical errors. Results are given for different state parameters in corresponding spectral windows together with the retrieval altitude resolution (Alt. reso.).

\begin{tabular}{lllll}
\hline Species & Spectral range $\left(\mathrm{cm}^{-1}\right)$ & Noise error $^{a}(\%)$ & Total error $^{a}(\%)$ & Alt. reso. (km) \\
\hline $\mathrm{ClO}$ & $821.0-841.5$ & $10-50^{\mathrm{b}}$ & $15-50^{\mathrm{b}}$ & $3-5$ \\
$\mathrm{ClONO}$ & $779.7-780.7$ & 2 & 6 & $2-3$ \\
$\mathrm{NO}_{2}$ & $1585.0-1615.0$ & $3-6$ & $10-12$ & $2-4$ \\
$\mathrm{~N}_{2} \mathrm{O}_{5}$ & $1220.0-1270.0$ & 2 & 6 & $3-5$ \\
\hline
\end{tabular}

a in the altitude region of the VMR maximum;

b daytime errors smaller than nighttime errors.

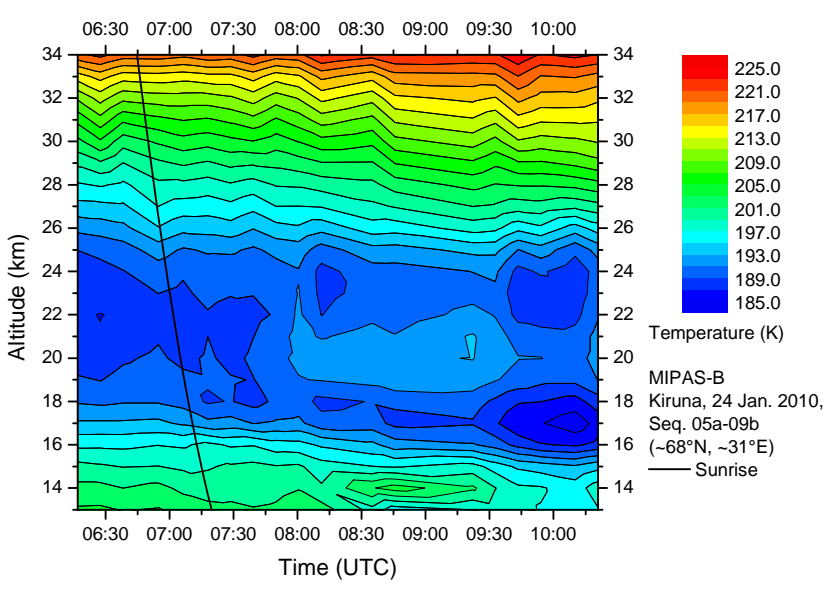

Fig. 3. Temperature as observed by MIPAS-B on 24 January 2010 above northern Scandinavia between 06:16 UTC and 10:20 UTC inside the Arctic vortex within the longitude/latitude sector shown in Fig. 1. The black solid line marks the sunrise terminator. Temperatures of less than $191 \mathrm{~K}$ occurred over a wide altitude region between about 16 and $26 \mathrm{~km}$.

sensitivity run was performed with the new absorption cross sections derived by Papanastasiou et al. (2009) which are recommended by Sander et al. (2011). The model output data was saved every $10 \mathrm{~min}$. The temporally closest output to the MIPAS-B measurements has been interpolated in space to the observed geolocations.

\section{Results and discussion}

In this section, profiles retrieved from MIPAS-B limb sequences measured before and after sunrise on 24 January 2010 are discussed and compared to chemical modelling. The sunrise took place between 06:44 UTC at $34 \mathrm{~km}$ and 07:19 UTC at $13 \mathrm{~km}$ altitude. Figure 3 shows the measured temperature cross section from 06:16 UTC to 10:20 UTC, corresponding to about $29^{\circ} \mathrm{E} / 69^{\circ} \mathrm{N}$ and $34^{\circ} \mathrm{E} / 67^{\circ} \mathrm{N}$. Very cold temperatures are visible in a broad layer between about 16 and $26 \mathrm{~km}$ which is slightly tilted from the western (left) to the eastern (right) part of the sounded vortex. This cold region was covered by numerous PSC mostly consisting of

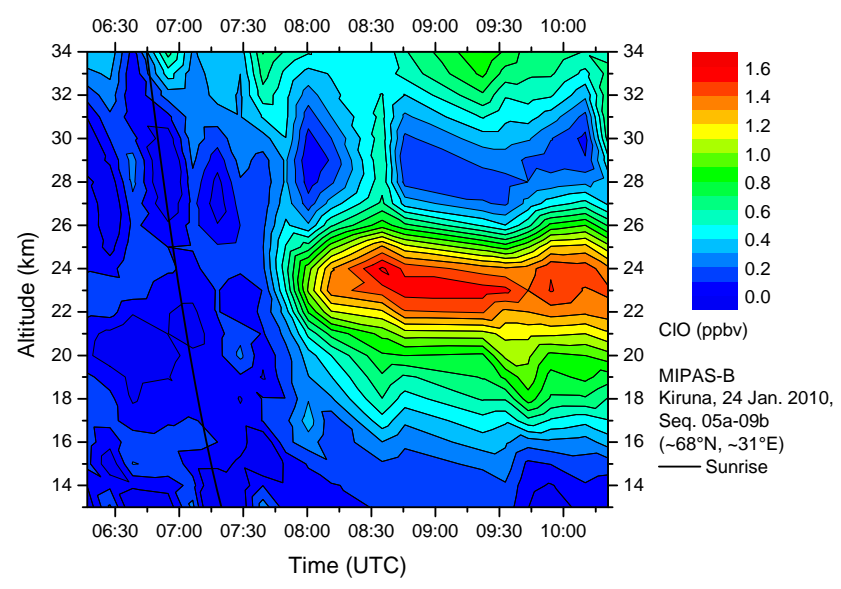

Fig. 4. Temporal evolution of chlorine monoxide $(\mathrm{ClO})$ as observed by MIPAS-B on 24 January 2010 above northern Scandinavia. A broad $\mathrm{ClO}$ layer with a pronounced $\mathrm{ClO}$ maximum of more than $1.6 \mathrm{ppbv}$ is visible. The strong photochemically induced increase in $\mathrm{ClO}$ mixing ratios starts about $45 \mathrm{~min}$ after sunrise due to the occurrence of stratospheric clouds. For details, see text.

STS as seen by spaceborne lidar observations (Pitts et al., 2011). Ten-days backward trajectories at $550 \mathrm{~K}(\sim 23 \mathrm{~km})$ show that the air parcels which were observed by MIPASB were transported inside the vortex and experienced cold temperatures below $T_{\mathrm{NAT}}$ most time of this period. Hence, a strong chemical activation of chlorine can be expected in the lower stratosphere.

The temporal variation of the important chlorine species $\mathrm{ClO}$ is shown in Fig. 4. A broad layer with enhanced $\mathrm{ClO}$ mixing ratios is visible between 16 and $26 \mathrm{~km}$ which coincides with the layer of coldest temperatures (cf. Fig. 3). Mixing ratios of up to $1.6 \mathrm{ppbv}$ are detected around $23 \mathrm{~km}$. High daytime $\mathrm{ClO}$ values of up to $1.2 \mathrm{ppbv}$ at $20 \mathrm{~km}$ have also been detected during a flight of the Geophysica aircraft over northern Scandinavia (Sumińska-Ebersoldt et al., 2012) on 30 January 2010 which are in line with MIPAS-B values near $1.0 \mathrm{ppbv}$ at this altitude. The diurnal variation of the concentration of $\mathrm{ClO}$ in the lower stratosphere is controlled by reaction scheme Reactions (R1) to (R4). Related to the sunrise terminator, the strong increase of the $\mathrm{ClO}$ concentration 


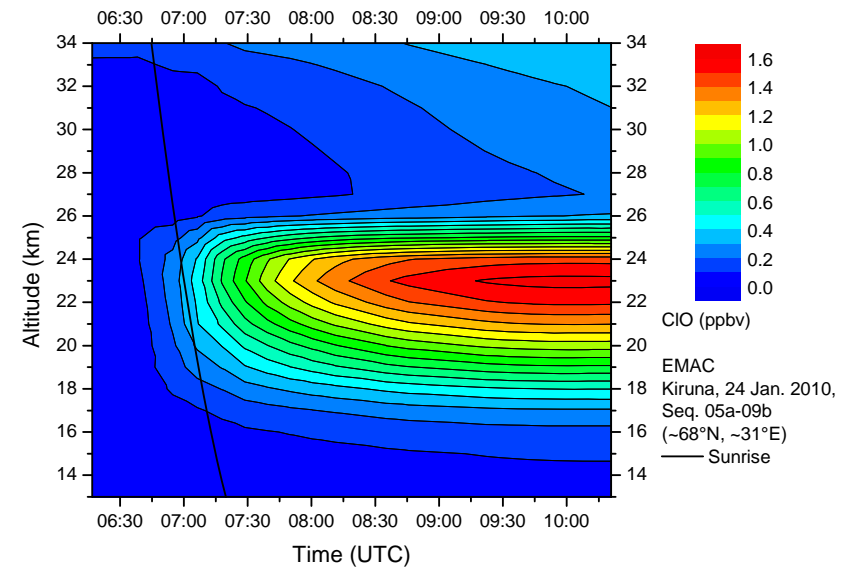

Fig. 5. Temporal evolution of $\mathrm{ClO}$ on 24 January 2010 as simulated by the chemical model EMAC. The build-up of $\mathrm{ClO}$ starts around sunrise. Maximum values of more than $1.6 \mathrm{ppbv}$ are reached during daytime.

due to photolysis of $\mathrm{ClOOCl}$ (Reaction R2) is delayed in the observations by about $45 \mathrm{~min}$. The terminator refers to the astronomical sunrise (with refraction) under cloudless conditions. However, the occurrence of clouds may, in principle, delay the onset of $\mathrm{ClOOCl}$ photolysis. Figure 5 shows the simulated variation of $\mathrm{ClO}$ as calculated by the chemical model EMAC. The simulated ClO layer peaks at the same altitude as the measured one does and calculated mixing ratios at $23 \mathrm{~km}$ are roughly the same as in the observation. Since cloudless conditions are assumed for the calculation of photochemical processes in EMAC, the increase of $\mathrm{ClO}$ starts already around sunrise, but with slower velocity compared to the MIPAS-B measurement. However, observed and modelled $\mathrm{ClO}$ daytime equilibrium values are reached at the same time with equal value. Besides the altitude of the $\mathrm{ClO}$ maximum, also the vertical extension of the enhanced $\mathrm{ClO}$ is very well reproduced by the model.

To figure out the delay in the measured onset of photolysis compared to EMAC, the influence of clouds on the photolysis of $\mathrm{ClOOCl}$ was investigated with the Tropospheric Ultraviolet-Visible (TUV) radiation model (Madronich and Flocke, 1998) developed at the Atmospheric Chemistry Division (ACD) at the National Center for Atmospheric Research (NCAR). Figure 6 shows a comparison of the buildup of $\mathrm{ClO}$ together with $\mathrm{ClOOCl}$ photolysis rates $\left(J_{\mathrm{ClOOCl}}\right)$ at $23 \mathrm{~km}$ altitude where maximum $\mathrm{ClO}$ mixing ratios were detected. The photolysis frequency calculations with varying cloud altitudes and optical thicknesses (for typical values see, e.g., Parol et al., 2000) exhibit that tropospheric clouds have no significant influence on the photolysis rate of the $\mathrm{ClO}$ dimer. This holds also for the ground surface albedo. Around sunrise, the diffuse radiation clearly dominates the photolysis rate. With decreasing SZA, the direct radiation gradually governs the photolysis rate of $\mathrm{ClOOCl}$. These conclusions

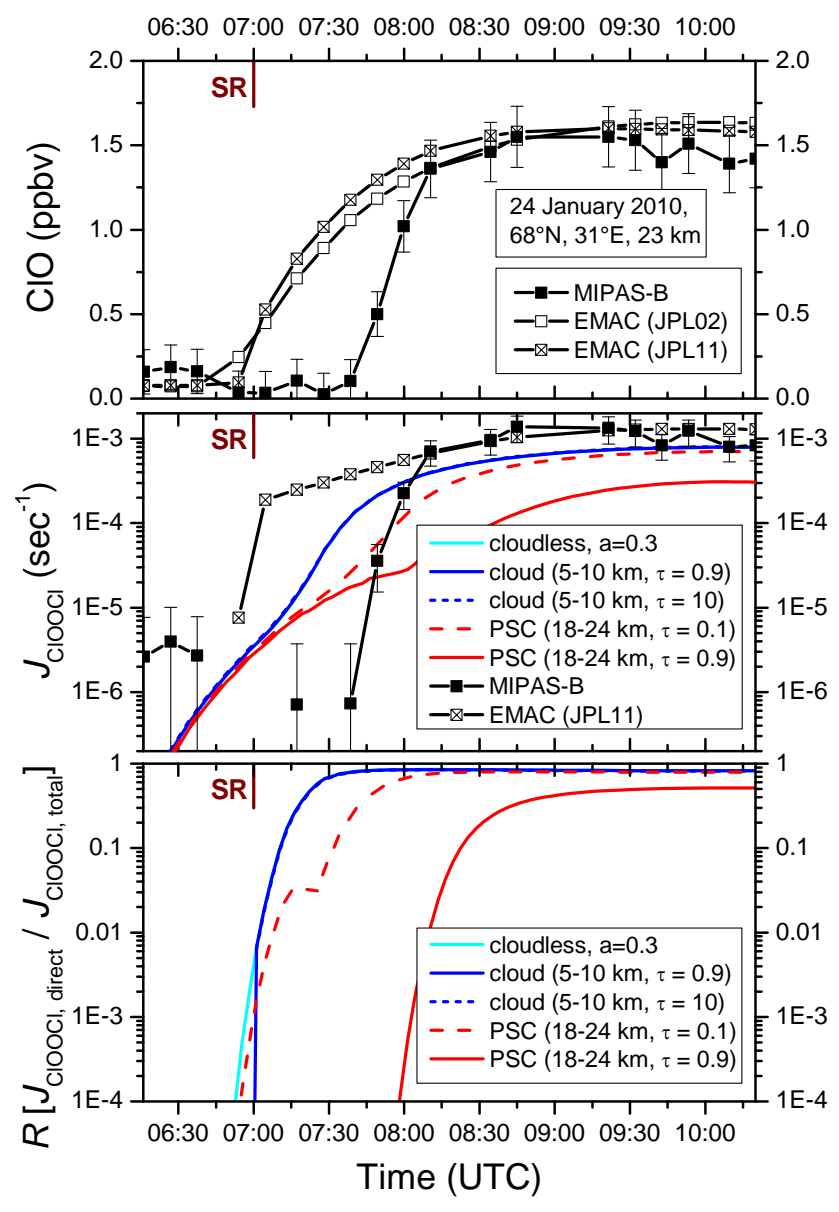

Fig. 6. Top panel: Measured and modelled build-up of $\mathrm{ClO}$ at $23 \mathrm{~km}$. $\mathrm{ClOOCl}$ absorption cross sections JPL02 (Sander et al., 2003) were used for the EMAC standard run. A sensitivity run was performed using new $\mathrm{ClOOCl}$ cross sections JPL11 (Sander et al. 2011). The delay in the observed $\mathrm{ClO}$ build-up is clearly visible. "SR" denotes astronomical sunrise. Middle panel: $\mathrm{ClOOCl}$ photolysis frequencies $\left(J_{\mathrm{ClOOCl}}\right)$ as calculated with the TUV (version 5.0) radiation model. For cloudless conditions, a ground surface albedo of $a=0.3$ was assumed. Clouds in different altitudes with typical optical thicknesses $(\tau)$ have been taken into account (bluish curves lie close together). Photolysis frequencies from EMAC and MIPAS-B (estimated assuming steady state, see text) are shown for comparison. While tropospheric clouds have no significant influence on the photolysis rate, PSC strongly affect $J_{\mathrm{ClOOCl}}$. Bottom panel: Ratio $R$ of the direct to total fraction of the $\mathrm{ClOOCl}$ photolysis frequency as calculated by TUV. Around sunrise, the diffuse radiation clearly dominates the $\mathrm{ClOOCl}$ photolysis rate.

are in agreement with the findings by Sumińska-Ebersoldt et al. (2012). However, reduced direct sunlight due to stratospheric clouds has a strong influence on the photolysis rate and the occurrence of PSC can therefore explain the delayed build-up in the measured $\mathrm{ClO}$ mixing ratio. For comparison, $J_{\mathrm{ClOOCl}}$ was estimated from MIPAS-B observations at $23 \mathrm{~km}$ assuming steady state using Reactions (R1) and (R2) 


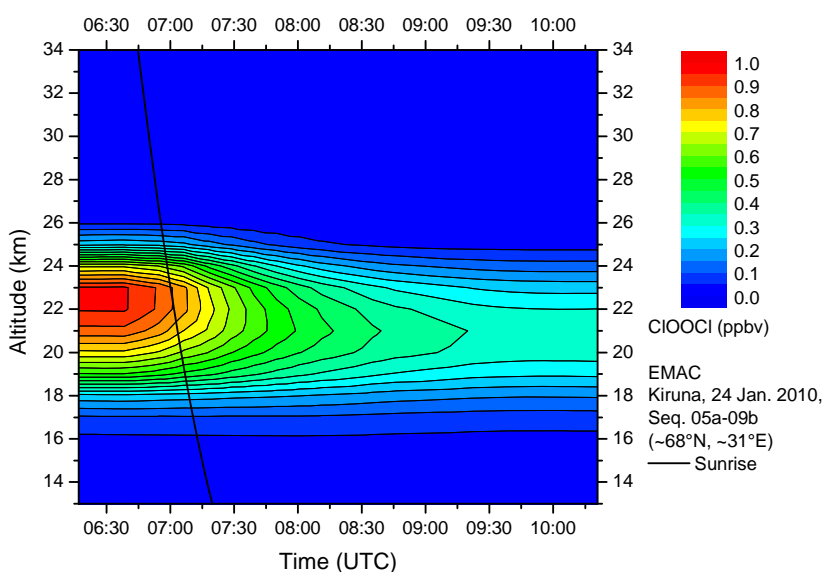

Fig. 7. Simulation of the chlorine monoxide dimer $\mathrm{ClOOCl}$ at the MIPAS-B measurement locations. The photodissociation starts at sunrise. For details, see text.

for production and loss of the $\mathrm{ClO}$ dimer together with the further assumptions that $[\mathrm{ClOOCl}]=\left(\left[\mathrm{ClO}_{\max }\right]-[\mathrm{ClO}]\right) / 2$ and $\left[\mathrm{ClO}_{\max }\right]=\left[\mathrm{ClO}_{\text {noon }}\right]+2\left[\mathrm{ClOOCl}_{\text {noon }}\right]$. Since the measured $\mathrm{ClO}$ at noon is roughly the same as in EMAC, $\mathrm{ClOOCl}$ at noon is taken directly from the model simulation. $J_{\mathrm{ClOOCl}}$ derived by MIPAS-B and the one simulated by EMAC are self-consistent with the particular increase in $\mathrm{ClO}$ mixing ratios. The delayed increase in $J_{\mathrm{ClOOCl}}$ from MIPAS-B due to the reduced direct illumination is clearly visible in Fig. 6 in line with the delayed increase in ClO VMR seen in Fig. 4. It should be mentioned that the assumption of steady state is not correct during the time of the strong increase in $\mathrm{ClO}$ VMR leading to an underestimation of $J_{\mathrm{ClOOCl}}$ in this short time interval. The use of JPL02 or JPL11 ClOOCl absorption cross sections only slightly alters the $\mathrm{ClO}$ increase simulated by EMAC.

The modelled variation of the chlorine monoxide dimer $\mathrm{ClOOCl}$ is depicted in Fig. 7. The diurnal variation of the amount of $\mathrm{ClOOCl}$ and $\mathrm{ClO}$ is governed by reaction scheme (R1) to (R4). High nighttime values close to $1.0 \mathrm{ppbv}$ are calculated by the model. The photodissociation of $\mathrm{ClOOCl}$ in favour of the production of $\mathrm{ClO}$ starts at sunrise in the model. Unfortunately, the dimer $\mathrm{ClOOCl}$ could not be unambiguously inferred from MIPAS-B spectra of this flight since the continuum-like emission of the ClOOCl $v_{1}$ band cannot be separated from the quasi-continuum emission induced by PSC particles in the corresponding altitude region. MIPAS$\mathrm{B}$ observations under comparable conditions in an activated chlorine layer (without PSC) in January 2001 revealed nighttime $\mathrm{ClOOCl}$ mixing ratios of nearly $1.1 \mathrm{ppbv}$ at $20 \mathrm{~km}$ (Wetzel et al., 2010) which are of comparable magnitude. The resulting $\mathrm{ClO}_{\mathrm{x}}$ in the model is about $2.1 \mathrm{ppbv}$ at its maximum. Taking also into account the species $\mathrm{HOCl}$ and $\mathrm{OClO}$, total $\mathrm{ClO}_{\mathrm{x}}$ values increase to $2.2 \mathrm{ppbv}$ at $23 \mathrm{~km}$. While $\mathrm{OClO}$ is not measurable by MIPAS-B, mean $\mathrm{HOCl}$ values (averaged

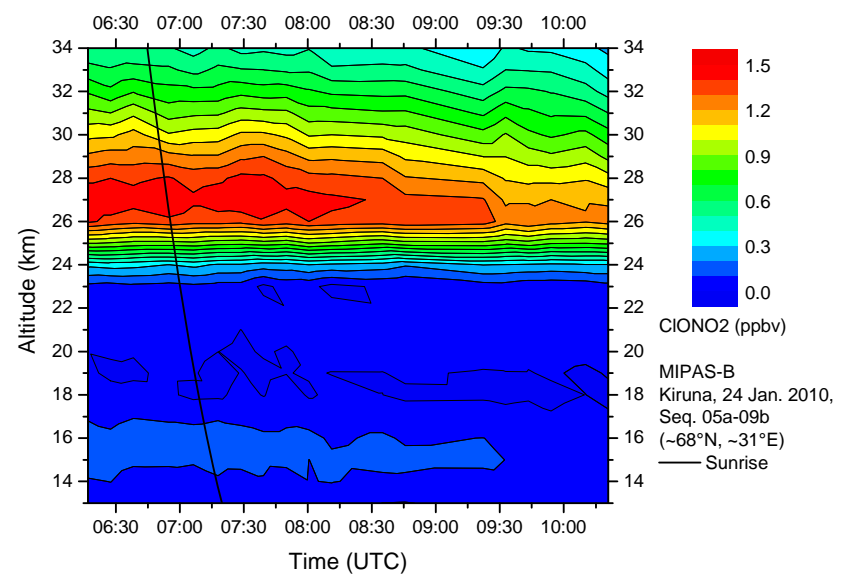

Fig. 8. $\mathrm{ClONO}_{2}$ mixing ratios as seen by MIPAS-B above northern Scandinavia on 24 January 2010 inside the polar vortex. Very low $\mathrm{ClONO}_{2}$ values below $24 \mathrm{~km}$ coincide with high amounts of activated chlorine.

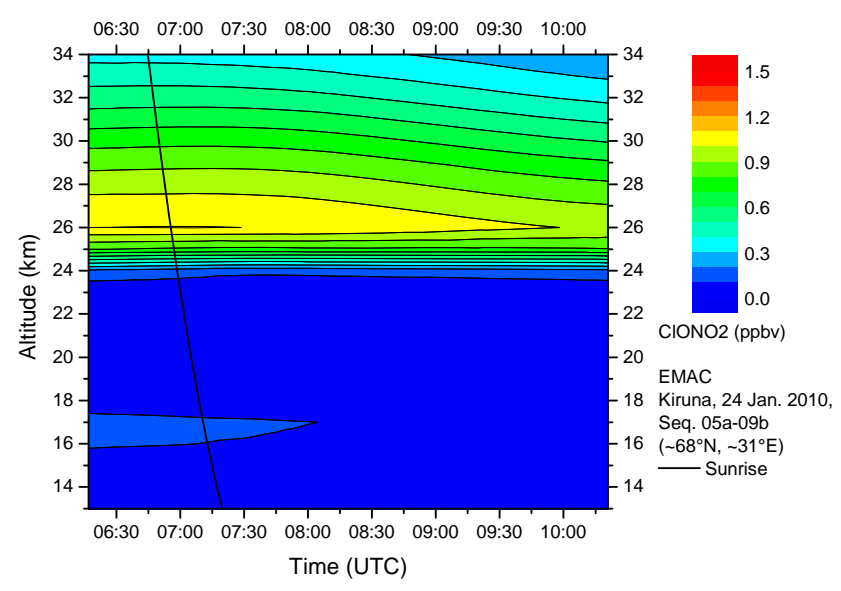

Fig. 9. $\mathrm{ClONO}_{2}$ mixing ratios on 24 January 2010 as simulated by the CCM EMAC.

over all measured sequences) amount to $0.2 \mathrm{ppbv}$ in this altitude region.

Large amounts of $\mathrm{ClO}_{\mathrm{x}}$ are connected with low amounts of the chlorine reservoir gas $\mathrm{ClONO}_{2}$ since the maximum of inorganic chlorine $\left(\mathrm{Cl}_{\mathrm{y}}=\mathrm{ClO}_{\mathrm{x}}+\mathrm{ClONO}_{2}+\mathrm{HCl}+\right.$ minor components) is a conserved quantity within the timeframe of one winter. Measured $\mathrm{ClONO}_{2}$ amounts are depicted in Fig. 8. $\mathrm{ClONO}_{2}$ values of up to $1.5 \mathrm{ppbv}$, which are not unusual for mid-winter conditions (Dufour et al., 2006), were measured at $27 \mathrm{~km}$. However, below $25 \mathrm{~km} \mathrm{ClONO} 2$ mixing ratios fall to values below $0.1 \mathrm{ppbv}$, coincident with the region of high $\mathrm{ClO}_{\mathrm{x}}$ amounts. The $\mathrm{ClONO}_{2}$ simulation by EMAC (see Fig. 9) yields significantly smaller mixing ratios of only $1.1 \mathrm{ppbv}$ as compared to the MIPAS-B observation, but at least in the same altitude region. At $26 \mathrm{~km}$, simulated $\mathrm{HCl}$ mixing ratios are close to $1.8 \mathrm{ppbv}$. Hence, in this altitude region and above, the partitioning between the chlorine 


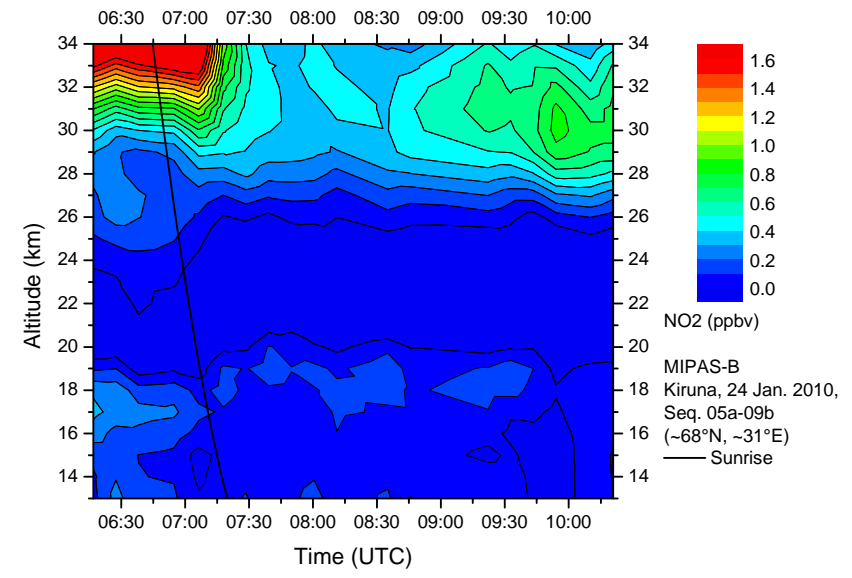

Fig. 10. $\mathrm{NO}_{2}$ mixing ratios retrieved from MIPAS-B spectra recorded around sunrise on 24 January 2010. The strong photochemically induced decrease of $\mathrm{NO}_{2}$ mixing ratios starts about 20 min after sunrise followed by a slower increase of $\mathrm{NO}_{2}$ amounts due to $\mathrm{N}_{2} \mathrm{O}_{5}$ photolysis. For details, see text.

reservoir species $\mathrm{ClONO}_{2}$ and $\mathrm{HCl}$ (which cannot be measured by MIPAS-B) seems to be shifted towards more $\mathrm{HCl}$ in the model compared to the observation (provided that the modelled $\mathrm{Cl}_{\mathrm{y}}$ is correct). Considering the zonal mean of the ratio between $\mathrm{HCl}$ and $\mathrm{ClONO}_{2}$ near $68^{\circ} \mathrm{N}$, we find that, around $26 \mathrm{~km}$, this quantity has not been changed significantly in the model between autumn 2009 and the time of the MIPAS-B observation. Simulated $\mathrm{Cl}_{\mathrm{y}}$ amounts to $3.2 \mathrm{ppbv}$ at $26 \mathrm{~km}$. Total $\mathrm{Cl}_{\mathrm{y}}$ can be estimated from measured $\mathrm{N}_{2} \mathrm{O}$ with the help of a $\mathrm{N}_{2} \mathrm{O}-\mathrm{Cl}_{\mathrm{y}}$ relationship as described by Wetzel et al. (2010). Taking into account a $-0.9 \%$ per year $\mathrm{Cl}_{\mathrm{y}}$ decrease since 2001 (WMO, 2011) we can confirm the EMAC value by estimating about $3.2 \mathrm{ppbv} \mathrm{Cl}_{\mathrm{y}}$ from the MIPAS-B $\mathrm{N}_{2} \mathrm{O}$ observations at $26 \mathrm{~km}$. Both, measurement and calculation exhibit a temporal decrease of the $\mathrm{ClONO}_{2}$ concentration from nighttime to local noon. This can be, at least to a large extent, attributed to the diurnal cycle of this species due to photolysis of $\mathrm{ClONO}_{2}$ after sunrise to produce $\mathrm{NO}_{3}$ and atomic $\mathrm{Cl}$ which will react mainly with $\mathrm{O}_{3}$ to form $\mathrm{ClO}$, and thus $\mathrm{ClO}_{\mathrm{x}}$ slightly increases after sunrise.

The molecule $\mathrm{ClONO}_{2}$ is also linked to the nitrogen family. As mentioned earlier, the availability of the species $\mathrm{NO}_{2}$ is important for the build-up of $\mathrm{ClONO}_{2}$ via Reaction (R5). $\mathrm{NO}_{2}$ is known to have a strong diurnal variation dependent on the SZA. The measured $\mathrm{NO}_{2}$ variation around sunrise is shown in Fig. 10. A strong decrease of $\mathrm{NO}_{2}$ about $20 \mathrm{~min}$ after sunrise is visible at altitudes above $30 \mathrm{~km}$. During daylight, $\mathrm{NO}_{2}$ is quickly transformed into $\mathrm{NO}$ via Reactions (R11) and (R12). The corresponding model calculation is depicted in Fig. 11. As expected, the simulated photodissociation of $\mathrm{NO}_{2}$ starts near sunrise because the model assumes cloudless conditions for the illumination. Modelled day- and nighttime quantities of $\mathrm{NO}_{2}$ are comparable to the measured

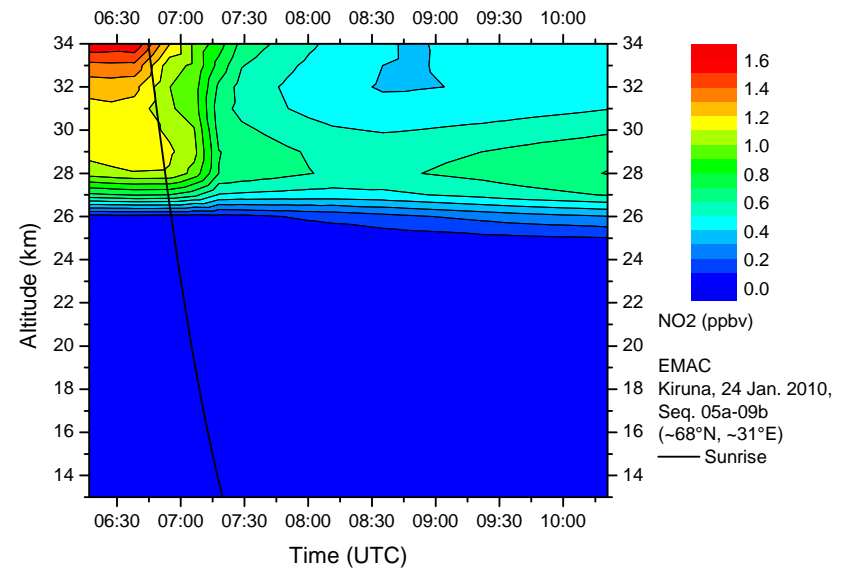

Fig. 11. Temporal evolution of $\mathrm{NO}_{2}$ amounts as calculated by EMAC.

ones but simulated temporal and vertical gradients are different from the observation. This might be explained by numerical smoothing (time steps and vertical resolution) and more $\mathrm{NO}_{\mathrm{y}}$ in the model (compared to the observation) below $30 \mathrm{~km}$. The measurement clearly exhibits the slow daytime increase of $\mathrm{NO}_{2}$ arising from the photolysis of $\mathrm{N}_{2} \mathrm{O}_{5}$ according to Reactions (R9) and (R10). This increase appears to be slightly weaker in the model calculation.

Figure 12. shows the temporal behaviour of $\mathrm{NO}_{2}$ together with its photolysis rates $\left(J_{\mathrm{NO}_{2}}\right)$ at $33 \mathrm{~km} . J_{\mathrm{NO}_{2}}$ from MIPAS$\mathrm{B}$ observations at $33 \mathrm{~km}$ was estimated assuming steady state taking into account Reactions (R6) and (R12) for production and loss of $\mathrm{NO}_{2}$ with the further assumption that $[\mathrm{NO}]=\left[\mathrm{NO}_{2}\right.$, night $]-\left[\mathrm{NO}_{2}\right]$. The delay in the observed $\mathrm{NO}_{2}$ decrease compared to astronomical sunrise and the EMAC simulation is reflected by the delayed increase in the observed photolysis rate. From the TUV radiation model simulations it is clear that again tropospheric clouds have virtually no influence on $J_{\mathrm{NO}_{2}}$ but a delay in the $J_{\mathrm{NO}_{2}}$ increase in the case of PSC is visible in the TUV simulation and the $J_{\mathrm{NO}_{2}}$ gradient is steeper than in the cloudless case. However, the influence of stratospheric clouds on the photolysis rate of $\mathrm{NO}_{2}$ is weaker than in the case of $J_{\mathrm{ClOOCl}}$ because the $\mathrm{NO}_{2}$ maximum is located above and not (like in the case of $\mathrm{ClO}$ and its dimer) in the PSC layer. Anyhow, the occurrence of $\mathrm{PSC}$ can also explain the measured delay in the $\mathrm{NO}_{2}$ decrease compared to astronomical sunrise.

The observed temporal evolution of $\mathrm{N}_{2} \mathrm{O}_{5}$ is illustrated in Fig. 13. Nighttime values close to $0.9 \mathrm{ppbv}$ at $28 \mathrm{~km}$ were measured just before sunrise where $\mathrm{N}_{2} \mathrm{O}_{5}$ reaches its diurnal maximum. The photolysis of $\mathrm{N}_{2} \mathrm{O}_{5}$ corresponding to (R9) begins shortly after sunrise. In accordance with theory, the photolysis rate is much slower than in the case of $\mathrm{NO}_{2}$. Hence, the delayed sunrise due to clouds is hardly visible in the photodissociation frequency of $\mathrm{N}_{2} \mathrm{O}_{5}$. The corresponding EMAC simulation is displayed in Fig. 14. The agreement 


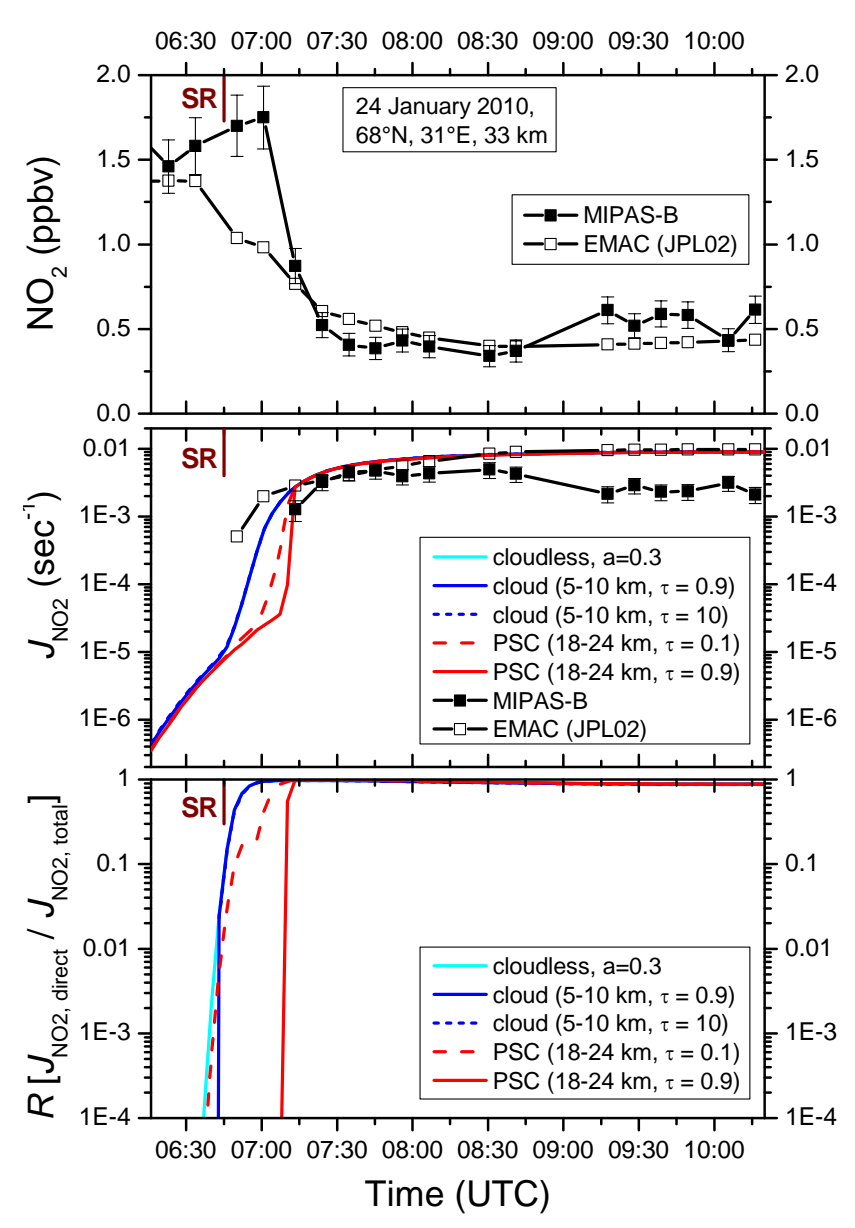

Fig. 12. Top panel: Measured and modelled temporal behaviour of $\mathrm{NO}_{2}$ at $33 \mathrm{~km}$. A temporal delay in the observed $\mathrm{NO}_{2}$ decrease after sunrise is clearly visible. Middle panel: $\mathrm{NO}_{2}$ photolysis frequencies $\left(J_{\mathrm{NO}_{2}}\right)$ as calculated with the TUV (version 5.0) radiation model (bluish curves lie close together) along with photolysis frequencies from EMAC and MIPAS-B (estimated assuming steady state, see text) are shown for comparison. While tropospheric clouds have no significant influence on the photolysis rate, PSC strongly affect $J_{\mathrm{NO}_{2}}$. Bottom panel: Ratio $R$ of the direct to total fraction of the $\mathrm{NO}_{2}$ photolysis frequency as calculated by TUV. Around sunrise, the diffuse radiation dominates the $\mathrm{NO}_{2}$ photolysis rate. Annotation as per Fig. 6 .

with measured $\mathrm{N}_{2} \mathrm{O}_{5}$ is close to perfect above $25 \mathrm{~km}$ with differences less than $0.1 \mathrm{ppbv}$. This holds not only for the magnitude and altitude of the VMR maximum but also for the decrease rate of $\mathrm{N}_{2} \mathrm{O}_{5}$. Below $25 \mathrm{~km}$, in contrast, the model overestimates the conversion of $\mathrm{N}_{2} \mathrm{O}_{5}$ into $\mathrm{HNO}_{3}$ by heterogeneous hydrolysis of $\mathrm{N}_{2} \mathrm{O}_{5}$ which takes place on sulphate aerosols and particles of PSC. On the other hand, MIPAS-B $\mathrm{N}_{2} \mathrm{O}_{5}$ mixing ratios below $25 \mathrm{~km}$ might be slightly overestimated due to interfering effects of the continuum-like emission of the $\mathrm{N}_{2} \mathrm{O}_{5} v_{12}$ band and the quasi-continuum emission induced by PSC particles. Further studies are required to investigate these differences.

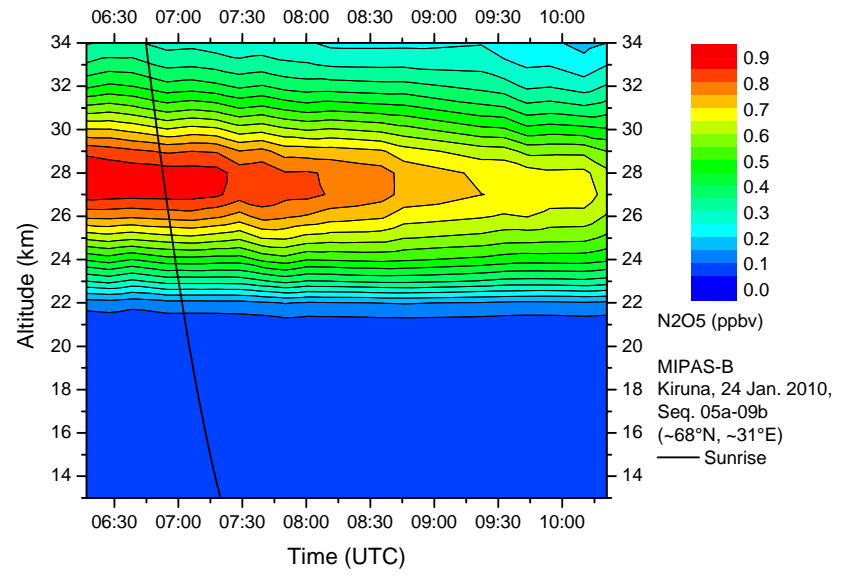

Fig. 13. $\mathrm{N}_{2} \mathrm{O}_{5}$ mixing ratios as measured by MIPAS-B on 24 January 2010 above northern Scandinavia. For details, see text.

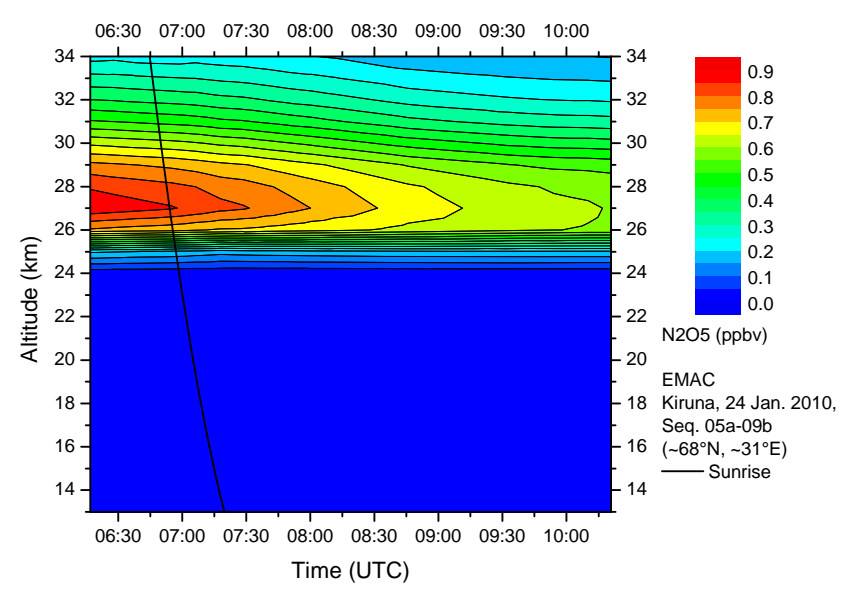

Fig. 14. Temporal evolution of $\mathrm{N}_{2} \mathrm{O}_{5}$ mixing ratios as calculated by EMAC.

\section{Conclusions}

The winter 2009/2010 was characterized by a strong polar vortex with extremely cold temperatures in the lower Arctic stratosphere in mid-winter. MIPAS-B limb emission measurements were carried out on 24 January 2010 just before a stratospheric warming induced rising temperatures. Low temperatures and concomitant PSC formation produced considerable amounts of active chlorine $\left(\mathrm{ClO}_{\mathrm{x}}\right)$ in a broad layer of the lower stratosphere between about 16 and $26 \mathrm{~km}$ which correlate with low quantities of its reservoir species $\mathrm{ClONO}_{2}$. The strong temporal change in $\mathrm{ClO}$ mixing ratios around the terminator between night and day was observed by MIPAS$\mathrm{B}$ for the first time. This concentration change is also visible in the simulation of the CCM EMAC. The time delay in the $\mathrm{ClO}$ build-up between MIPAS-B and EMAC could be reduced if the model was able to simulate reduced illumination caused by reduced direct sunlight due to stratospheric clouds. Anyhow, measured and modelled daytime 
equilibrium $\mathrm{ClO}$ mixing ratios (about $1.6 \mathrm{ppbv}$ ) are in perfect agreement. To calculate correct chlorine activation in the sounded air masses, the temperature history of the air parcels is an important issue, because it is crucial whether PSC were present resulting in chlorine activation at their particle surfaces.

The photochemically active nitrogen containing molecules $\mathrm{NO}_{2}$ and $\mathrm{N}_{2} \mathrm{O}_{5}$ are correlated with each other and exhibit the expected changes after sunrise. While the comparatively slow $\mathrm{N}_{2} \mathrm{O}_{5}$ variation above $25 \mathrm{~km}$ is nearly perfectly reproduced by EMAC, the quick change in $\mathrm{NO}_{2}$ mixing ratios proceeds slower in the model than observed. The faster photodissociation rate in the measurement can be explained by the delayed but enhanced illumination when the sun is rising above stratospheric clouds (due to the lower sunrise SZA compared to cloudless conditions).

We conclude that during night and noon the modelling of chlorine and nitrogen containing species is well performed by EMAC. However, the onset of $\mathrm{ClO}$ production and $\mathrm{NO}_{2}$ loss around the terminator in the model is not consistent with the measurements. The time delay in the measured onset of photodissoziation of $\mathrm{ClOOCl}$ and $\mathrm{NO}_{2}$ near the morning terminator by about 45 and $20 \mathrm{~min}$, respectively, leading to later but faster production of $\mathrm{ClO}$ and later but faster reduction of $\mathrm{NO}_{2}$ are explained by stratospheric clouds which reduce the direct radiative flux from the sun. The difference in the time delays depends on the location of the PSC layer with respect to the photochemically active layer. These effects are not considered in the EMAC model simulations. Heterogeneous chlorine activation, which is strongly dependent on the correct modelling of stratospheric temperatures and concomitant PSC formation, is also captured by EMAC quite well.

Acknowledgements. We are grateful to the Swedish Space Corporation (SSC) launching team at Esrange for excellent balloon operations and logistical assistance and the Free University of Berlin for meteorological support (especially K. Grunow). We thank S. Madronich from National Center for Atmospheric Research (NCAR) Atmospheric Chemistry Division (ACD) for providing us with the TUV radiation model. This work was funded in part by the European Space Agency (ESA) and the German Aerospace Center (DLR). We acknowledge support by Deutsche Forschungsgemeinschaft and Open Access Publishing Fund of Karlsruhe Institute of Technology.

The service charges for this open access publication have been covered by a Research Centre of the Helmholtz Association.

Edited by: C. McNeil

\section{References}

Brasseur, G. and Solomon, S.: Aeronomy of the middle atmosphere (third edition), Atmos. Oceanograph. Sci. Lib., 369 pp., Springer, Dordrecht, The Netherlands, 2005.

Carslaw, K. S., Luo, B., and Peter, T.: An analytic expression for the composition of aqueous $\mathrm{HNO}_{3}-\mathrm{H}_{2} \mathrm{SO}_{4}$ stratospheric aerosols including gas phase removal of $\mathrm{HNO}_{3}$, Geophys. Res. Lett., 22, 1877-1880, 1995.

Douglass, A. R., Schoeberl, M. R., Stolarski, R. S., Waters, J. W., Russell III, J. M., Roche, A. E., and Massie, S. T.: Interhemispheric differences in springtime production of $\mathrm{HCl}$ and $\mathrm{ClONO}_{2}$ in the polar vortices, J. Geophys. Res., 100, 13967-13978, 1995.

Dufour, G., Nassar, R., Boone, C. D., Skelton, R., Walker, K. A., Bernath, P. F., Rinsland, C. P., Semeniuk, K., Jin, J. J., McConnell, J. C., and Manney, G. L.: Partitioning between the inorganic chlorine reservoirs $\mathrm{HCl}$ and $\mathrm{ClONO}_{2}$ during the Arctic winter 2005 from the ACE-FTS, Atmos. Chem. Phys., 6, 23552366, doi:10.5194/acp-6-2355-2006, 2006.

Fahey, D. W., Gao, R. S., Carslaw, K. S., Kettleborough, J., Popp, P. J., Northway, M. J., Holecek, J. C., Ciciora, S. C., McLaughlin, R. J., Thompson, T. L., Winkler, R. H., Baumgardner, D. G., Gandrud, B., Wennberg, P. O., Dhaniyala, S., McKinney, K., Peter, Th., Salawitch, R. J., Bui, T. P., Elkins, J. W., Webster, C. R., Atlas, E. L., Jost, H., Wilson, J. C., Herman, R. L., Kleinböhl, A., and von König, M.: The detection of large $\mathrm{HNO}_{3}$-containing particles in the winter Arctic stratosphere, Science, 291, 1026-1031, 2001.

Friedl-Vallon, F., Maucher, G., Kleinert, A., Lengel, A., Keim, C., Oelhaf, H., Fischer, H., Seefeldner, M., and Trieschmann, O.: Design and characterization of the balloon-borne Michelson Interferometer for Passive Atmospheric Sounding (MIPAS-B2), Appl. Opt., 43, 3335-3355, 2004.

Funke, B., López-Puertas, M., von Clarmann, T., Stiller, G. P., Fischer, H., Glatthor, N., Grabowski, U., Höpfner, M, Kellmann, S., Kiefer, M., Linden, A., Mengistu Tsidu, G., Milz, M., Steck, T., and Wang, D. Y.: Retrieval of stratospheric $\mathrm{NO}_{\mathrm{x}}$ from 5.3 and $6.2 \mu \mathrm{m}$ nonlocal thermodynamic equilibrium emissions measured by Michelson Interferometer for Passive Atmospheric Sounding (MIPAS) on Envisat, J. Geophys. Res., 110, D09302, doi:10.1029/2004JD005225, 2005.

Glatthor, N., von Clarmann, T., Fischer, H., Grabowski, U., Höpfner, M., Kellmann, S., Kiefer, M., Linden, A., Milz, M., Steck, T., Stiller, G. P., Mengistu Tsidu, G., and Wang, D.-Y.: Spaceborne $\mathrm{ClO}$ observations by the Michelson Interferometer for Passive Atmospheric Sounding (MIPAS) before and during the Antarctic major warming in September/October 2002, J. Geophys. Res., 109, D11307, doi:10.1029/2003JD004440, 2004. Höpfner, M., Oelhaf, H., Wetzel, G., Friedl-Vallon, F., Kleinert, A., Lengel, A., Maucher, G., Nordmeyer, H., Glatthor, N., Stiller, G., von Clarmann, T., Fischer, H., Kröger, C., and Deshler, T.: Evidence of scattering of tropospheric radiation by PSCs in mid-IR limb emission spectra: MIPAS-B observations and KOPRA simulations, Geophys. Res. Lett., 29, 1278, doi:10.1029/2001GL014443, 2002.

Höpfner, M., Larsen, N., Spang, R., Luo, B. P., Ma, J., Svendsen, S. H., Eckermann, S. D., Knudsen, B., Massoli, P., Cairo, F., Stiller, G., v. Clarmann, T., and Fischer, H.: MIPAS detects Antarctic stratospheric belt of NAT PSCs caused by mountain waves, Atmos. Chem. Phys., 6, 1221-1230, doi:10.5194/acp-6-1221-2006, 
2006.

Höpfner, M., von Clarmann, T., Fischer, H., Funke, B., Glatthor, N., Grabowski, U., Kellmann, S., Kiefer, M., Linden, A., Milz, M., Steck, T., Stiller, G. P., Bernath, P., Blom, C. E., Blumenstock, Th., Boone, C., Chance, K., Coffey, M. T., Friedl-Vallon, F., Griffith, D., Hannigan, J. W., Hase, F., Jones, N., Jucks, K. W., Keim, C., Kleinert, A., Kouker, W., Liu, G. Y., Mahieu, E., Mellqvist, J., Mikuteit, S., Notholt, J., Oelhaf, H., Piesch, C., Reddmann, T., Ruhnke, R., Schneider, M., Strandberg, A., Toon, G., Walker, K. A., Warneke, T., Wetzel, G., Wood, S., and Zander, R.: Validation of MIPAS $\mathrm{ClONO}_{2}$ measurements, Atmos. Chem. Phys., 7, 257-281, doi:10.5194/acp-7-257-2007, 2007.

IPCC (Intergovernmental Panel on Climate Change): Climate Change 2001: Synthesis Report. A Contribution of Working Groups I, II and III to the Third Assessment Report of the Intergovernmental Panel on Climate Change, edited by: Watson, R. T. and the Core Writing Team, Cambridge University Press, Cambridge, UK, and New York, USA, 2001.

Jöckel, P., Sander, R., Kerkweg, A., Tost, H., and Lelieveld, J.: Technical Note: The Modular Earth Submodel System (MESSy) - a new approach towards Earth System Modeling, Atmos. Chem. Phys., 5, 433-444, doi:10.5194/acp-5-433-2005, 2005.

Jöckel, P., Tost, H., Pozzer, A., Brühl, C., Buchholz, J., Ganzeveld, L., Hoor, P., Kerkweg, A., Lawrence, M. G., Sander, R., Steil, B., Stiller, G., Tanarhte, M., Taraborrelli, D., van Aardenne, J., and Lelieveld, J.: The atmospheric chemistry general circulation model ECHAM5/MESSy1: consistent simulation of ozone from the surface to the mesosphere, Atmos. Chem. Phys., 6, 50675104, doi:10.5194/acp-6-5067-2006, 2006.

Kerzenmacher, T., Wolff, M. A., Strong, K., Dupuy, E., Walker, K. A., Amekudzi, L. K., Batchelor, R. L., Bernath, P. F., Berthet, G., Blumenstock, T., Boone, C. D., Bramstedt, K., Brogniez, C., Brohede, S., Burrows, J. P., Catoire, V., Dodion, J., Drummond, J. R., Dufour, D. G., Funke, B., Fussen, D., Goutail, F., Griffith, D. W. T., Haley, C. S., Hendrick, F., Höpfner, M., Huret, N., Jones, N., Kar, J., Kramer, I., Llewellyn, E. J., López-Puertas, M., Manney, G., McElroy, C. T., McLinden, C. A., Melo, S., Mikuteit, S., Murtagh, D., Nichitiu, F., Notholt, J., Nowlan, C., Piccolo, C., Pommereau, J.-P., Randall, C., Raspollini, P., Ridolfi, M., Richter, A., Schneider, M., Schrems, O., Silicani, M., Stiller, G. P., Taylor, J., Tétard, C., Toohey, M., Vanhellemont, F., Warneke, T., Zawodny, J. M., and Zou, J.: Validation of $\mathrm{NO}_{2}$ and NO from the Atmospheric Chemistry Experiment (ACE), Atmos. Chem. Phys., 8, 5801-5841, doi:10.5194/acp-8-5801-2008, 2008.

Khosrawi, F., Urban, J., Pitts, M. C., Voelger, P., Achtert, P., Kaphlanov, M., Santee, M. L., Manney, G. L., Murtagh, D., and Fricke, K.-H.: Denitrification and polar stratospheric cloud formation during the Arctic winter 2009/2010, Atmos. Chem. Phys., 11, 8471-8487, doi:10.5194/acp-11-8471-2011, 2011.

Kirner, O., Ruhnke, R., Buchholz-Dietsch, J., Jöckel, P., Brühl, C., and Steil, B.: Simulation of polar stratospheric clouds in the chemistry-climate-model EMAC via the submodel PSC, Geosci. Model Dev., 4, 169-182, doi:10.5194/gmd-4-169-2011, 2011.

Landgraf, J. and Crutzen, P. J.: An efficient method for online calculations of photolysis and heating rates, J. Atmos. Sci., 55, 863878,1998

Madronich, S. and Flocke, S.: The role of solar radiation in atmospheric chemistry, in Handbook of Environmental Chem- istry, edited by: Boule, P., Springer-Verlag, Heidelberg, Germany, 1998, 1-26, 1998.

Mengistu Tsidu, G., Stiller, G. P., von Clarmann, T., Funke, B., Höpfner, M., Fischer, H., Glatthor, N., Grabowski, U., Kellmann, S., Kiefer, M., Linden, A., López-Puertas, M., Milz, M., Steck, T., and Wang, D. Y.: $\mathrm{NO}_{\mathrm{y}}$ from Michelson Interferometer for Passive Atmospheric Sounding on Environmental Satellite during the Southern Hemisphere polar vortex split in September/October 2002, J. Geophys. Res., 110, D11301, doi:10.1029/2004JD005322, 2005.

Molina, M. J., Tso, T.-L., Molina, L. T., and Wang, F. C.-Y.: Antarctic stratospheric chemistry of chlorine nitrate, hydrogen chloride, and ice: Release of active chlorine, Science, 238, 1253-1257, 1987.

Montzka, S. A., Butler, J. H., Elkins, J. W., Thompson, T. M., Clarke, A. D., and Lock, L. T.: Present and future trends in the atmospheric burden of ozone-depleting halogens, Nature, 398, 690-694, 1999.

Müller, R., Peter, Th., Crutzen, P. J., Oelhaf, H., Adrian, G. P., von Clarmann, Th., Wegner, A., Schmidt, U., and Lary, D.: Chlorine chemistry and the potential for ozone depletion in the Arctic stratosphere in the winter of 1991/92, Geophys. Res. Lett., 21, 1427-1430, 1994.

Nash, E. R., Newman, P. A., Rosenfield, J. E., and Schoeberl, M. R.: An objective determination of the polar vortex using Ertel's potential vorticity, J. Geophys. Res., 101, 9471-9478, 1996.

Oelhaf, H., von Clarmann, T., Fischer, H., Friedl-Vallon, F., Fritzsche, C., Linden, A., Piesch, C., Seefeldner, M., and Völker, W.: Stratospheric $\mathrm{ClONO}_{2}$ and $\mathrm{HNO}_{3}$ profiles inside the Arctic vortex from MIPAS-B limb emission spectra obtained during EASOE, Geophys. Res. Lett., 21, 1263-1266, 1994.

Papanastasiou, D. K., Papadimitriou, V. C., Fahey, D. W., and Burkholder, J. B.: UV Absorption Spectrum of the ClO Dimer $\left(\mathrm{Cl}_{2} \mathrm{O}_{2}\right)$ between 200 and $420 \mathrm{~nm}$, J. Phys. Chem. A, 113, 13711-13726, doi:10.1021/jp9065345, 2009.

Parol, F., Descloitres, J., and Fouquart, Y.: Cloud optical thickness and albedo retrievals from bidirectional reflectance measurements of POLDER instruments during ACE-2, Tellus, 52B, 888-908, 2000.

Phillips, D.: A technique for the numerical solution of certain integral equations of the first kind, J. Assoc. Comput. Math., 9, 84-97, 1962.

Pitts, M. C., Poole, L. R., Dörnbrack, A., and Thomason, L. W.: The 2009-2010 Arctic polar stratospheric cloud season: a CALIPSO perspective, Atmos. Chem. Phys., 11, 2161-2177, doi:10.5194/acp-11-2161-2011, 2011.

Prinn, R. G., Huang, J., Weiss, R. F., Cunnold, D. M., Fraser, P. J., Simmonds P. G., McCulloch, A., Harth, C., Salameh, P., O’Doherty, S., Wang, R. H. J., Porter, L., and Miller, B. R.: Evidence for substantial variations of atmospheric hydroxyl radicals in the past two decades, Science, 292, 1882-1888, 2001.

Roeckner, E., Brokopf, R., Esch, M., Giorgetta, M., Hagemann, S., Koernblueh, L., Manzini, E., Schlese, U., and Schulzweida, U.: Sensitivity of simulated climate to horizontal and vertical resolution in the ECHAM5 atmosphere model, J. Climate, 19, 37713791, 2006.

Rothman, L. S., Jacquemart, D., Barbe, A., Benner, D. C., Birk, M., Brown, L. R., Carleer, M. R., Chackerian Jr., C., Chance, K., Coudert, L. H., Dana, V., Devi, V. M., Flaud, J.-M., Gamache, 
R. R., Goldman, A., Hartmann, J.-M., Jucks, K. W., Maki, A. G., Mandin, J.-Y., Massie, S. T., Orphal, J., Perrin, A., Rinsland, C. P., Smith, M. A. H., Tennyson, J., Tolchenov, R. N., Toth, R. A., Vander Auwera, J., Varanasi, P., and Wagner, G.: The HITRAN 2004 molecular spectroscopic database, J. Quant. Spectrosc. Radiat. Transfer, 96, 139-204, 2005.

Sander, R., Kerkweg, A., Jöckel, P., and Lelieveld, J.: Technical note: The new comprehensive atmospheric chemistry module MECCA, Atmos. Chem. Phys., 5, 445-450, doi:10.5194/acp-5445-2005, 2005.

Sander, S. P., Friedl, R. R., Golden, D. M., Kurylo, M. J., Huie, R. E., Orkin, V. L., Moortgat, G. K., Ravishankara, A. R., Kolb, C. E., Molina, M. J., and Finlayson-Pitts, B. J.: Chemical kinetics and photochemical data for use in atmospheric studies, Evaluation no. 14, JPL Publ. 02-25, Jet Propulsion Laboratory, Pasadena, CA, USA, 2003.

Sander, S. P., Friedl, R. R., Barker, J. R., Golden, D. M., Kurylo, M. J., Wine, P. H., Abbatt, J., Burkholder, J. B., Kolb, C. E., Moortgat, G. K., Huie, R. E., and Orkin, V. L.: Chemical kinetics and photochemical data for use in atmospheric studies Evaluation no. 17, JPL Publ. 10-6, Jet Propulsion Laboratory, Pasadena, CA, USA, 2011.

Santee, M. L., Manney, G. L., Waters, J. W., and Livesey, N. J.: Variations and climatology of $\mathrm{ClO}$ in the polar lower stratosphere from UARS Microwave Limb Sounder measurements, J. Geophys. Res., 108, 4454, doi:10.1029/2002JD003335, 2003.

Santee, M. L., MacKenzie, I. A., Manney, G. L., Chipperfield, M. P., Bernath, P. F., Walker, K. A., Boone, C. D., Froidevaux, L., Livesey, N. J., and Waters, J. W.: A study of stratospheric chlorine partitioning based on new satellite measurements and modelling, J. Geophys. Res., 113, D12307, doi:10.1029/2007JD009057, 2008.

Solomon, S., Garcia, R. R., Rowland, F. S., and Wuebbles, D. J.: On the depletion of Antarctic ozone, Nature, 321, 755-758, 1986.

Spang, R., Remedios, J. J., and Barkley, M. P.: Colour indices for the detection and differentiation of cloud types in infra-red limb emission spectra, Adv. Space Res., 33, 1041-1047, 2004.

Stiller, G. P., von Clarmann, T., Funke, B., Glatthor, N., Hase, F., Höpfner, M., and Linden, A.: Sensitivity of trace gas abundances retrievals from infrared limb emission spectra to simplifying approximations in radiative transfer modeling, J. Quant. Spectrosc. Radiat. Transfer, 72, 249-280, 2002.

Stimpfle, R. M., Wilmouth, D. M., Salawitch, R. J., and Anderson, J. G.: First measurements of $\mathrm{ClOOCl}$ in the stratosphere: The coupling of $\mathrm{ClOOCl}$ and $\mathrm{ClO}$ in the Arctic polar vortex, J. Geophys. Res., 109, D03301, doi:10.1029/2003JD003811, 2004.

Sumińska-Ebersoldt, O., Lehmann, R., Wegner, T., Grooß, J.-U., Hösen, E., Weigel, R., Frey, W., Griessbach, S., Mitev, V., Emde, C., Volk, C. M., Borrmann, S., Rex, M., Stroh, F., and von Hobe, $\mathrm{M}$.: $\mathrm{ClOOCl}$ photolysis at high solar zenith angles: analysis of the RECONCILE self-match flight, Atmos. Chem. Phys., 12, 1353-1365, doi:10.5194/acp-12-1353-2012, 2012.

Tikhonov, A.: On the solution of incorrectly stated problems and a method of regularization, Dokl. Acad. Nauk SSSR, 151, 501504, 1963.

von Hobe, M., Salawitch, R. J., Canty, T., Keller-Rudek, H., Moortgat, G. K., Grooß, J.-U., Müller, R., and Stroh, F.: Understanding the kinetics of the $\mathrm{ClO}$ dimer cycle, Atmos. Chem. Phys., 7, 3055-3069, doi:10.5194/acp-7-3055-2007, 2007.
Waibel, A. E., Peter, T., Carslaw, K. S., Oelhaf, H., Wetzel, G., Crutzen, P. J., Pöschl, U. Tsias, A., Reimer, E., and Fischer, H.: Arctic ozone loss due to denitrification, Science, 283, 2064-2068, 1999.

Wetzel, G., Oelhaf, H., von Clarmann, T., Fischer, H., Friedl-Vallon, F., Maucher, G., Seefeldner, M., Trieschmann, O., and Lefèvre, F.: Vertical profiles of $\mathrm{N}_{2} \mathrm{O}_{5}, \mathrm{HO}_{2} \mathrm{NO}_{2}$, and $\mathrm{NO}_{2}$ inside the Arctic vortex, retrieved from nocturnal MIPAS-B2 infrared limb emission measurements in February 1995, J. Geophys. Res., 102, 19177-19186, 1997.

Wetzel, G., Oelhaf, H., Ruhnke, R., Friedl-Vallon, F., Kleinert, A., Kouker, W., Maucher, G., Reddmann, T., Seefeldner, M., Stowasser, M., Trieschmann, O., von Clarmann, T., and Fischer, $\mathrm{H}$.: $\mathrm{NO}_{\mathrm{y}}$ partitioning and budget and its correlation with $\mathrm{N}_{2} \mathrm{O}$ in the Arctic vortex and in summer mid-latitudes in 1997, J. Geophys. Res., 107, 4280, doi:10.1029/2001JD000916, 2002.

Wetzel, G., Bracher, A., Funke, B., Goutail, F., Hendrick, F., Lambert, J.-C., Mikuteit, S., Piccolo, C., Pirre, M., Bazureau, A., Belotti, C., Blumenstock, T., De Mazière, M., Fischer, H., Huret, N., Ionov, D., López-Puertas, M., Maucher, G., Oelhaf, H., Pommereau, J.-P., Ruhnke, R., Sinnhuber, M., Stiller, G., Van Roozendael, M., and Zhang, G.: Validation of MIPASENVISAT $\mathrm{NO}_{2}$ operational data, Atmos. Chem. Phys., 7, 32613284, doi:10.5194/acp-7-3261-2007, 2007.

Wetzel, G., Oelhaf, H., Kirner, O., Ruhnke, R., Friedl-Vallon, F., Kleinert, A., Maucher, G., Fischer, H., Birk, M., Wagner, G., and Engel, A.: First remote sensing measurements of $\mathrm{ClOOCl}$ along with $\mathrm{ClO}$ and $\mathrm{ClONO}_{2}$ in activated and deactivated Arctic vortex conditions using new $\mathrm{ClOOCl}$ IR absorption cross sections, Atmos. Chem. Phys., 10, 931-945, doi:10.5194/acp-10-931-2010, 2010.

Wiegele, A., Kleinert, A., Oelhaf, H., Ruhnke, R., Wetzel, G., Friedl-Vallon, F., Lengel, A., Maucher, G., Nordmeyer, H., and Fischer, H.: Spatio-temporal variations of $\mathrm{NO}_{\mathrm{y}}$ species in the northern latitudes stratosphere measured with the balloonborne MIPAS instrument, Atmos. Chem. Phys., 9, 1151-1163, doi:10.5194/acp-9-1151-2009, 2009.

WMO (World Meteorological Organization): Scientific Assessment of Ozone Depletion: 2006, Global Ozone Research and Monitoring Project - Report No. 50, 572 pp., Geneva, Switzerland, 2007.

WMO (World Meteorological Organization): Scientific Assessment of Ozone Depletion: 2010, Global Ozone Research and Monitoring Project - Report No. 52, 516 pp., Geneva, Switzerland, 2011.

Wolff, M. A., Kerzenmacher, T., Strong, K., Walker, K. A., Toohey, M., Dupuy, E., Bernath, P. F., Boone, C. D., Brohede, S., Catoire, V., von Clarmann, T., Coffey, M., Daffer, W. H., De Mazière, M., Duchatelet, P., Glatthor, N., Griffith, D. W. T., Hannigan, J., Hase, F., Höpfner, M., Huret, N., Jones, N., Jucks, K., Kagawa, A., Kasai, Y., Kramer, I., Küllmann, H., Kuttippurath, J., Mahieu, E., Manney, G., McElroy, C. T., McLinden, C., Mébarki, Y., Mikuteit, S., Murtagh, D., Piccolo, C., Raspollini, P., Ridolfi, M., Ruhnke, R., Santee, M., Senten, C., Smale, D., Tétard, C., Urban, J., and Wood, S.: Validation of $\mathrm{HNO}_{3}, \mathrm{ClONO}_{2}$, and $\mathrm{N}_{2} \mathrm{O}_{5}$ from the Atmospheric Chemistry Experiment Fourier Transform Spectrometer (ACE-FTS), Atmos. Chem. Phys., 8, 3529-3562, doi:10.5194/acp-8-3529-2008, 2008. 